\title{
STRATEGI SEGMENTASI PADA INDUSTRI KERIPIK
}

\author{
Muslimah \\ Universitas Terbuka
}

a. Profil Perusahaan: Industri Kecil Menengah (IKM) Madani adalah perusahaan yang bergerak dibidang makanan dengan konsentrasi produk oleh-oleh Khas Ende dalam bentuk produk Kripik berbagai jenis seperti singkong, pisang, ubi ungu dan keladi dengan bermacam-macam rasa

b. Jenis produk yang dijual dan harganya:

Macam-macam Kripik

Kripik Pisang berbagai rasa (asin manis, asin) harga Rp.10.000, - Rp.20.000,

Kripik Singkong harga (balado, asin manis, keju, jagung bakar, original, balado hijau, asin) Rp.10.000, Rp.20.000,

Kripik Ubi Ungu (original) Rp.10.000, - Rp. 15.000,

Kripik Keladi (balado, asin manis, keju, jagung bakar, original, balado hijau, asin) Rp.10.000, - Rp.20.000,

c. Bentuk Promosi apa yang dilakukan: spanduk, selebaran/leaflet, penempatan produk di tempat produksi, toko induk dan supermarket yang ada di Kabupaten Ende

d. Siapa saja Konsumen yang membeli produknya: Sasaran konsumen adalah Pelancong/turis lokal yang menginginkan oleh-oleh khas Ende dan masyarakat Kabupaten Ende.

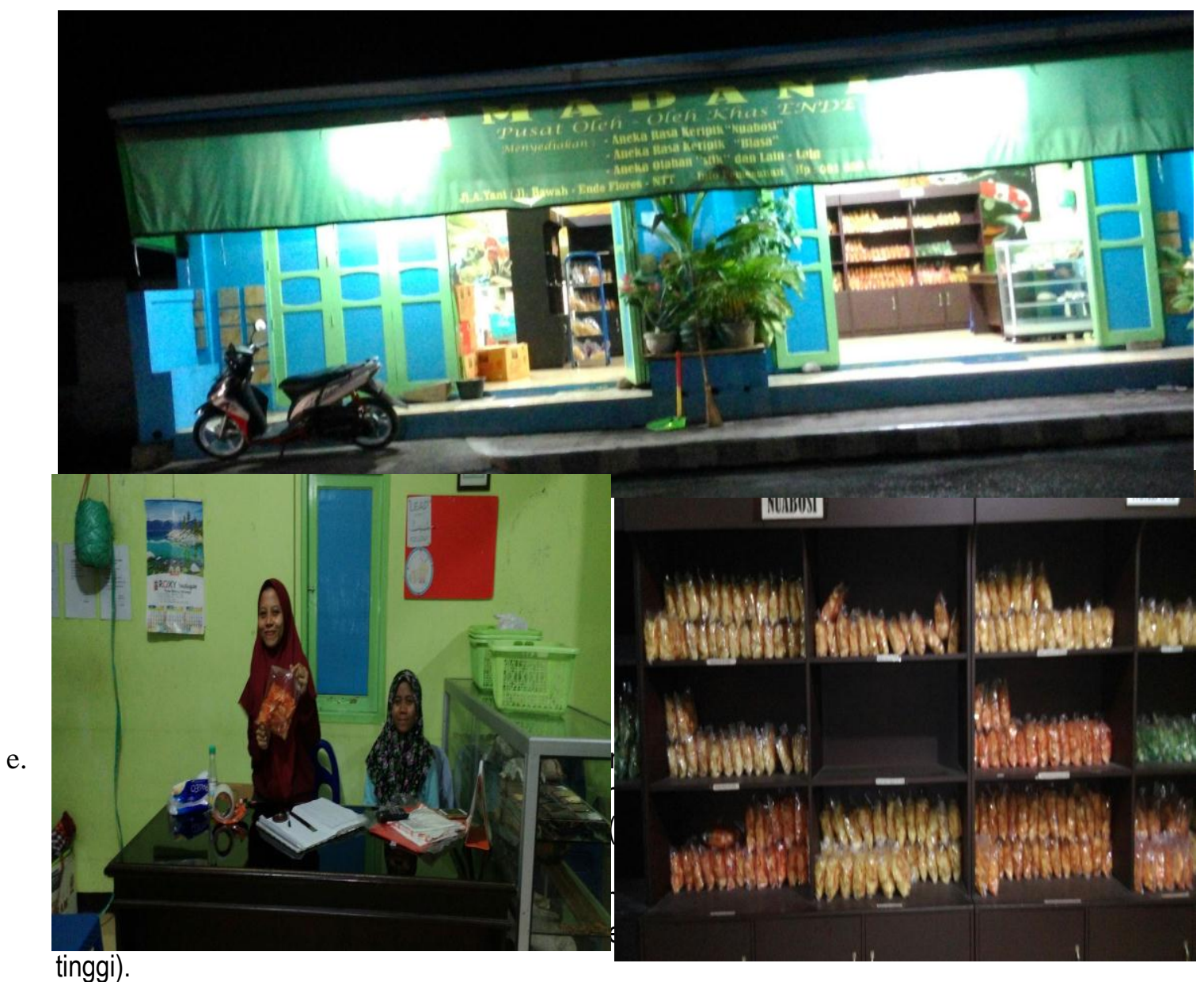


Karena segmentasi pasar sudah terlayani meskipun belum memuaskan dan jumlah pesaing yang melayani segmen ini masih sedikit sehingga peluang pasar yang ada masih besar. Sehingga penentuan pasar sasaran atau penargetan pasar produk ini masih cukup besar. Peluang usaha berkembang semakin jelas dengan penyediaan bahan baku yang melimpah dan terpenuhinya tenaga kerja melalui pelatihan keterampilan memudahkan perusahaan melakukan ekspansi produk ke luar wilayah Kabupaten Ende. Karena iklim tropis cenderung panas, penyediaan bahan baku sangat mudah didapat oleh perusahaan. Melihat persaingan produk serupa belum terlalu signifikan memungkin produk perusahaan berupa oleh-oleh khas jadi sasaran konsumen baik masyarakat umum yang ada di Kabupaten Ende maupun pelancong yang berkunjung di daerah ini. Dengan lancarnya moda transportasi terlebih transportasi udara memungkinkan penyebaran produk lebih banyak ke berbagai wilayah, terutama di wilayah Nusa Tenggara Timur dan Pulau Jawa. Pemilihan produksi beupa produk olahan dari tanaman asli oleh perusahaan sangat cocok dengan faktor demografis geografis yang ada di Kabupaten Ende ini.

1. Sebutkan strategi apa saja yang perlu dilakukan agar usaha tersebut berada pada posisi yang terbaik di pasar?

a. Strategi penetrasi pasar, yaitu strategi pemasaran yang dilakukan perusahaan dalam melayani pasar yang ada, atau menjangkau pelanggan-pelanggan baru dengan karakteristik yang sama, dengan menggunakan bauran pemasaran yang ada.

b. Strategi pengembangan produk, yaitu strategi pemasaran yang dilakukan perusahaan dalam melayani segmen pelanggan yang ada dengan menawarkan lebih dari satu bauran pemasaran.

c. Strategi pengembangan pasar, yaitu strategi pemasaran yang ditujukan untuk melayani lebih dari satu segmen pelanggan dengan menggunakan satu bauran pemasaran.

\section{DAFTAR PUSTAKA:}

Dharmmesta, Basu Swastha. 2019. Materi pokok manajemen pemasaran. Edisi kedua. Tangerang Selatan: Penerbit Universitas Terbuka.

Fadillah, A., Sujana, S. and Sukartaatmadja, I., 2019. Kajian Minat Studi Lanjut Siswa-Siswi SMA dan SMK Kota Bogor Ke Perguruan Tinggi. JAS-PT (Jurnal Analisis Sistem Pendidikan Tinggi Indonesia), 3(1), pp.53-62.

Mulyana, M., 2019. MENGANALISIS PERILAKU KONSUMEN.

Mulyana, M., 2019. STRATEGI PROMOSI DAN KOMUNIKASI.

Mulyana, M., Hidayat, L. and Puspitasari, R., 2019. Mengukur Pengetahuan Investasi Para Mahasiswa Untuk Pengembangan Galeri Investasi Perguruan Tinggi. JAS-PT (Jurnal Analisis Sistem Pendidikan Tinggi Indonesia), 3(1), pp.31-52.

Sulistiono, S., Nurendah, Y. and Mulyana, M., 2019. Mengukur Minat Studi Siswa SMA dan SMK di Kota Bogor Pada Program Studi Kewirausahaan. JAS-PT (Jurnal Analisis Sistem Pendidikan Tinggi Indonesia), 3(1), pp.1-12.

Sukartaatmadja, I., Thoyibah, H., Mulyana, M. and Yusdira, A., 2019. PELATIHAN DIGITAL LIBRARY BAGI PENGELOLA PERPUSTAKAAN PERGURUAN TINGGI SE-BOGOR.

Setiawan, B., Puspitasari, R. and Manurung, T.M.S., 2016. The existence of Islamic banking in Indonesia from non-muslims perceptions. ASEAN Marketing Journal, pp.81-96.

Hidayat, L., Amwilla, A.Y. and Aprilia, A., 2015. Analisis Perputaran Modal Kerja, Perputaran Aktiva Terhadap Tingkat Pengembalian Modal. Jurnal IImiah Manajemen Kesatuan, 3(1).

Purba, J.H.V. and Munawar, A., 2008. Kajian Dampak Pelatihan terhadap Kinerja Karyawan. Jurnal IImiah Ranggagading (JIR), 8(2), pp.95-102. 
Purba, J.H.V. and Hartoyo, S., 2018. Dampak Kenaikan Harga Minyak Bumi terhadap Permintaan CPO untuk Biodiesel dan Beberapa Aspek Pada Industri Kelapa Sawit Indonesia. JIMFE (Jurnal IImiah Manajemen Fakultas Ekonomi), 2(1), pp.37-49. 